Croatian International Relations Review

-

XXVI (86) 2020,

$42-70$

DOI $10.37173 /$

cirr.26.86.2

-

UDC 427(477:470+571)

\title{
Crimea as Saguntum?
}

A Phenomenological Approach to the Ukrainian Crisis within the Framework of a Transforming Post-Bipolar Structure

\section{Yunus Emre Özigci}

(Université Catholique de Louvain, Belgium)

Ministry of Foreign Affairs of the Republic of Turke ${ }^{*}$

emremisik@icloud.com

ORCID: 0000-0003-3388-7149

\section{Abstract}

Key words:

Crimea;

Phenomenologv;

Unipolarity; Russia;

Ukraine
The developments in Ukraine in 2014, namely the annexation of Crimea and the secessionist upheaval in Donetsk and Lugansk areas caused - or appeared as the content of - a rift between the "West" and Russia. The core questions of this article explore the nature of this rift and its significance on the shape of the international system in their relatedness to the Ukrainian crisis.

The concepts employed in the study belong to phenomenology as adapted to the field of international relations, in order to answer to the apparent need to develop a tool that would enable us to ground the study on its subjective/intersubjective infrastructure that is adequate to the nature of the concepts of state, territory, international system and relations.

Within this framework, the Ukrainian crisis and Crimean annexation appear as a positional and systemic content that marks a new temporal phase of the post-bipolar intersubjectivity. An existential framework shall thus be provided to policy contents, as a posteriori yet "real" elements of the phenomena which mav be extended, on subjective/intersubjective grounds of international relations, towards positional and systemic horizons as defining and restraining fundamentals of causal interactions.

* Currently employed as Head of Department at the Ministry of Foreign Affairs of the Republic of Turkey. The paper constitutes a personal work and does not reflect the views of the Ministry of Foreign Affairs of the Republic of Turkey. 


Croatian
International
Relations
Review
-
CIRR
-
XXVI (86) 2020,
$42-70$

$42-70$

\section{Introduction}

Secessionist movements that evolved into frozen conflicts have constituted a particular phenomenon related to the exUSSR countries during the post-bipolar era. The distinguishing factor of those conflicts from the others throughout the globe is that they almost invariably posited fault lines on a larger scale, involving clear reciprocal position-takings among the ex-opponents of the Cold War era. They arose in countries that had shown a tendency to change alignment - which would have a meaning only on retention of the bipolar period, with the opposition's stance against that change along with its original agenda (on the latter point, see Souleimanov 2013). These movements generally succeeded in securing territory and found support on a logic inherited from bipolarity/ bipolarisation. The government that had to face the secessionist movement and de facto lost territory, in its turn, was supported to varying degrees and forms by the ex-opposing camp on the same logic (see Coyle 2018'). These include Transnistria (Jackson 2003: 81-111, Kennedy 2016), Abkhazia (Jackson 2003: 112-139), South Ossetia (Lemay-Hebert 2008), and Lugansk-Donetsk cases, while Nagorno-Karabakh presents some differences due to the nature and the sides of the conflict (Vaserman, Ginat 1994, Souleimanov 2013).

The importance of these conflicts, beyond their fundamental causes and outcomes, resides on their implications on the international system structure. They constitute spatial dividing lines that transcend their scale. As such, they become the contents of a more encompassing, systemic level contradiction. Their "freeze" further underlines this situation, contributing to the durability of the systemic level differences, while themselves gaining durability from the same source.

However, their being "frozen" also ensures that their systemiclevel consequences are contained. They are, in large part, reconfined to the countries they occur in with secessionist entities gaining at least a de facto status of counterpart. Furthermore, their resolution is locked to some internal/international process or a soft balancing action, and the involvement level/escalation potential of their supporting actors is thus restrained. With the freeze of the conflict, the sides involved

1 Coyle's fairly recent work gives a good account of the frozen conflicts, including their background, crises periods, involved actors' attitudes and processes of (un)resolution. 
Croatian

International

Relations

Review

$-$

CIRR

$-$

XXVI (86) 2020,

$42-70$ may preserve their position. Consequently, the systemic-level supporters gain a margin of manoeuvre to circumvent the conflict in their relations, while they also preserve their stance regarding the conflict.

The Crimean part of the Ukrainian crisis seems to differ from this general picture. It is the first time since the end of the bipolar/bipolarised era that a significant power incorporated part of the territory of an independent - and westward shifting - country. The Crimean crisis shows a novelty in terms of engagement of one exogenous side of such conflicts in that particular political geography. The annexation of the Peninsula, notwithstanding the international law debate on the matter, created serious and possibly systemic repercussions.

In this paper, the crisis, and its implications for the involved actors and the international system shall be examined through the employment of the concepts and methods belonging to phenomenology. The first chapter shall be reserved to outline those concepts and the reasons for their use. The phenomenon is to be studied concerning its link with the actors' positions and their systemic references that transcend the causal factors while positing their framework. The aim is to handle the phenomenon on a subjective/intersubjective ground adequate to the nature of the very concepts of territory, state, international politics and international system and to develop an explanatory tool that would complement causal studies and their theoretical approaches generally based on objectivisation of phenomena.

In the second chapter, we shall concentrate our attention on the systemic temporality of the post-bipolar/unipolar era, its constituent actors and Ukraine in its positional temporality within. We will meditate upon the constant reference of noeticnoematic processes to the intersubjective constitution of the international system and its encompassing presence in the constitution of the Ukrainian state of affairs.

In the third chapter, we shall examine the subjective/ intersubjective infrastructure of the Ukrainian/Crimean crisis within our conceptual framework. There we will try to show how the Crimean annexation constituted a content that marked the passage to a new phase of post-bipolar/unipolar systemic temporality and related positional phases for the main actors 
Croatian

International

Relations

Review

CIRR

XXVI (86) 2020,

$42-70$

of the system. The characteristics of the new phase shall be described accordingly, departing from the single phenomenon of Crimea towards the intersubjective system.

\section{Subjective/Intersubjective Grounds of International Relations and the employment of the concepts of Phenomenology}

\section{Subjective/Intersubjective infrastructure of International Relations}

The study of international relations with all its diversity as to the conceptualisation, approaches and methods, has a fundamental point of departure. It assumes the existence of state, territory, international relations themselves, even an international system, before dissecting them. The assumption is neither inherently negative nor invalid. Moreover, eliminating assumption from experiences, acts and thought processes is neither necessary nor possible for it would posit solus ipse (but see Ricoeur 2005 and Gander 2017: 138 for the solus ipse problem related to ego-cogito) depriving the subject of objects and the directionality of any thought. Assumption of the existence of things constitutes, therefore, the fundamental noetic-noematic act that establishes the connection of ego-cogito (see Husserl 1982: 7-19; 25-26 for ego-cogito's separate presence, Husserl 1983: 5-6) to reality ${ }^{2}$. Therefore, the assumption in its pure form as the act is inherently valid. In contrast, the validity of the "assumed" as the object of predication/judgment is a posteriori to it (see Husserl 1982: 10-11; Husserl 1983: 105-107), another noeticnoematic process (see Husserl 1983: 58-60, Foellesdal 2005 (1969)) with varying modalities. It is the "natural attitude" in Husserlian terms, the natural state of existence where thought, experience, and judgmental/predicative acts relate the subject to the reality through the fundamental assumption and render the subject a part of the assumed reality (see Husserl 1983: 51-57)

The second, a posteriori part of this fundamental act becomes problematic when the assumed thing has no correspondence in immediately accessible reality. The assumption, in this case, appears "empty" at first sight yet its noematic correlate is posited, nevertheless. In a particular field of study where predication, judgment and theorisation are not only present

2 Being put in perspective through the universal epoche, by the suspension of the fundamental assumption and all its contents as pertaining to the "reality". 


Croatian
International
Relations
Review
-
CIRR
-
XXVI (86) 2020,
$42-70$

Croatian

International

Relations

Review

CIRR

XXVI (86) 2020

$42-70$ but employed in building further causal structures, not only on the fundamental act of assumption but also on the "assumed" that does not correspond to immediate reality, the reality as accessed becomes $h p b r i d$. It does not translate into invalidity either but alters and expands the reality to which its validity is related. Here, the assumed is incorporated into causality through the intersubjectivity of the assumption. In other words, by rendering an intersubjective constitution to a part of the causal interactions within the reality, the validity of the assumed is secured in an altered environment, more intersubjective than objective. The reality becomes itself intersubjectively constituted (Schnell 2010). The natural attitude is thus rooted in a subjective/intersubjective ground.

The problem arises from that point on and is in no case related to the validity of the reality thus expanded. Natural attitude, when related to international relations, pursues another noetic-noematic act that is the objectivisation of the expanded reality through the assumed. The act of objectivisation runs in the reverse direction of assumption in relation to its subjective/intersubjective ground. The assumed is either overlooked as assumed and is dealt with as if it was a directly accessible part of the reality, or is "explained" within causality through theorisation belonging to natural attitude (see Husserl 1983: 7-18;35-39;45-48, Husserl 1970: 48-53), such as psychology, sociology and derivatives. Such a causal study does not suffer from invalidity either. Nevertheless, it is restrained by denaturing the assumed content as well as the expansion of reality. Its validity does not encompass the subjective/ intersubjective ground of phenomena.

The consequence is to overlook the noetic-noematic processes that do not only provide the phenomena with their existential ground but also the framework they impose on causal interactions involving purely constituted elements. To begin with, the objectivisation of the state as an actor of international relations, which is equivalent to cutting the link between the assumed and the mechanism of assumption with all that it attributes to the assumed, releases the causal parameters from their existential framework. In a secondary effort of theorisation within causality, the study of the actor and its interactions becomes possible, however, through the priorities and methods pertaining to a reduced object in a reduced environment. The objectivisation replaces the subjective/ 


Croatian
International
Relations
Review
-
CIRR
-
XXVI (86) 2020,
$42-70$

Croatian International Relations Review intersubjective infrastructure when its validity should be assessed on that background.

Therefore, the study of the subjective/intersubjective infrastructure becomes necessary in order to complement the study restrained to causality. Hence the need for a phenomenological approach to the reality in its expanded form, to the subjects and phenomena related to its expansion. It would aim at establishing a link with the intersubjective infrastructure and develop an explanatory tool for the existentially regulating framework of the constituted actors, phenomena, and interactions within reality (see Husserl 1970: 143-148). That study, as mentioned, is not to replace but to complement the existing approaches.

Within this framework, the natural attitude, the prevalence of which is the reason for imposing objectivisation, is to be suspended. Epoche does not ignore or attempt to erase the elements of reality. It is the bracketing of the natural attitude and its contents with the fundamental act of assumption (Husserl 1982: 7-9, Husserl 1983: 67-69)3. ${ }^{3}$ It is, therefore, a change of attitude in relation to what is being "assumed". It thus becomes possible to clarify the nature of the phenomenon as a phenomenon, noetic-noematic acts as such, and contents as contents. The phenomenological reduction does not carry us to solus ipse either. It carries us instead to the sphere of noeticnoematic processes pertaining to the constitution of reality as well as that of the subject as part of it, where intersubjectivity is not assumed but pre-given (see Gander 2017: 94-964, Heidegger 1996: 117-1185; Husserl 1970: 184-186). Through epoche, it becomes possible to reach to the actor as position among the multitude of actors in-position within the systemic framework co-constituted as shaped intersubjectivity. Intersubjectivity is attributed with a shape on its being itself a noematic correlate, with its noematic core and strata. If the noematic strata depend instead on the modalities of related noetic-noematic processes of individual actors, the noematic core to which they refer must be uniform. The uniformity is not only due to the

3 In Cartesian Meditations for the "Cartesian overthrow" and in Ideen I concerning the need for a firm axiomatic ground as ego-cogito through universal epoche.

4 Gander's reference to Riedel's dialogic approach to cogito that leads to pre-givenness of intersubjectivity through that of the other in the language is something we would disagree with, given that the language itself is not pre-given.

5 Heidegger's reasoning concerning the Mitdasein as the basis of the possibility of Husserlian Einfuehlung leads to pre-givenness of the intersubjectivity of the Lebenswelt. 
Croatian

International

Relations

Review

$-$

CIRR

$-$

XXVI (86) 2020,

$42-70$ pre-givenness of intersubjectivity but also to its simplified nature since it is itself "derived" as its constituent subjects are "derived", themselves constituted (see Carr 1987: 267/ 2812996). Intersubjectivity's shape as noematic core is nothing but a standard reference among the actors where the secondary attributions as strata are also bracketed. The example is as follows. Unipolarity, as a noematic core, stands unbracketed, while the general attitude of the actor towards unipolarity, including secondary modalities that produce predicative or judgmental contents, is suspended. Those suspended are to be incorporated into the study, within the framework stemming from the subjective/intersubjective infrastructure that becomes reachable through epoche.

Lastly, it needs underlining here that the phenomenological approach to IR is fundamentally different from constructivist or post-structuralist ones. Epoche is neither abstraction nor deconstruction. Subjective/intersubjective infrastructure does neither equal narration as act nor is constructed by a narrator-group that would define things and situations in their Weltanschauung at that level. Any Weltanschauung is "constituted". The said does not deny the existence of a narrative and a narrator. However, they are necessarily $a$ posteriori, and they make part of our investigation as contents, not within the noetic-noematic processes of (intersubjectively attributed to) the derived-subject. They are posited through the objectivisation and shape the reality on the pre-present intersubjective infrastructure. They are not by nature different than social/psychological research conducted through the same objectivisation of the subjective/intersubjective field and the act of constitution. De facto and frequently, they restrain themselves within the hybrid-causality by attributing the act of constitution to social strata, especially the elites. They prefer, therefore, to depart from the "constituted" to reach the "constituted" in terms of meaning attribution. The same is valid for the language as well. It is also a posteriori to the act of meaning attribution as the formulation and expression of forms and contents. The subjectivity/intersubjectivity of these works thus become not only "posited" itself, but also reduced to forms, as a simulacrum of subjectivity in an objectivised environment. Therefore, they are themselves a posteriori to the fundamental act of assumption, only returning to

6 On the constitution of We-subject as a simulacrum of ego-cogito (cogitamus ergo sumus), with "intentional properties ascribed to them." 


Croatian
International
Relations
Review
-
CIRR
-
XXVI (86) 2020,
$42-70$

$42-70$ the "assumed" in a critical sense within the hybrid-reality. In short, they operate within the natural attitude, and despite the similarities with our work, at first sight, they indeed have nothing in common with it.

\section{Temporality}

Until now, the study on the subjective/intersubjective infrastructure and the establishment of a link with the constitution of reality has instead been described as resembling taking a picture of international relations. Time here is the missing dimension. All noetic-noematic processes are temporal acts that ensure the necessary continuity of the actor and the system even when they appear inert. The temporality of the actor and the system constitutes, beyond an object of study of our phenomenological approach, a fundamental component of it that makes the study possible.

In this context, two forms of temporality shall be considered. The first is the temporal act of retention-protention (see Carr 1991: 24, 40-45; Husserl 1964: 39-50). It is the constitution of "now" with related contents (see Olbromski 2007). The actor as a derived subject must always retain itself as position, its acts, and experiences and the intersubjectivity as the environment with all "bracketed" contents. Thus, it is not "a remembrance of the past" but the fundamental continuation mechanism of the self and the intersubjective environment. In other words, it is the permanent constitution of the self that appresents the rest. The recollection of particular events and situations may not be classified separately from retention (but see Carr 1991: 21-27)7. What is recollected in an intentional act sends part of this study as long as it is incorporated by the same act, into the retention. As for the protention, it is to be defined as the continuity - act of retention, its extension into the near future in what is retained, assuring the permanent constitution of "now". "Now" may not be posited without retention and protention, for it does not exist as a given moment. It is posited as continually vanishing, and it gains existence only in extension backwards and forwards. Retentionprotention, as a fundamental temporal act of the subject, is also

7 We would disagree with Carr and Husserl on the separation of the recollection from the retention. Recollection would be valid only as retentional content as transformed into it. For the derived-subject, there is even no need for "transformation", for the recollection would not exist except the general contents of "historicity" of the derived-subject. 


Croatian
International
Relations
Review
-
CIRR
-
XXVI (86) 2020,
$42-70$

Croatian

International

Relations the primary mode of all noetic-noematic processes (see also Husserl 1964: 87).

The second temporal form in our study is anticipation. It includes the noetic-noematic processes related to the actor and the system, with all modalities and contents, in future in general. Its distinction from retention-protention is its nonlinearity. Anticipation is positing on a horizon on which the actor, system and contents are to take the substance in such-and-such form. Through epoche, the unbracketed act appears as multipleended. It is not a causal process involving probabilities. On the contrary, causal interaction elements are either bracketed or not attributed, depending on the conduct of the mere study. Still, the horizon as posited is neither amorphous nor infinite. It posits a framework stemming from retention-protention not only of actor's position and its modalities but also that of the ever-present systemic reference due to the constant positing of the intersubjective environment (see Heidegger 1996: 97-100; and Marion 1998: 77-97) ${ }^{8}$. Therefore, the anticipation's horizon is the framework of contents and forms to beattributed, in the form of foreign policy acts, including predicative and judgmental ones. Study of anticipation through epoche gives the regulating/ restraining intersubjective horizon of causality, to which the bracketed contents belong and where they are formed.

Our approach thus involves the study of the temporality of the actor and the system. Consequently, the noetic-noematic processes of the subject are to be stressed by the term positioning as their temporal form. Notable as well is its link with the position to be defined in contents within the causality.

\section{Contents within their noetic-noematic framework}

We defined the phenomenological attitude as complementary to the existing studies, which are valid yet restrained to the study of the contents through objectivisation of the elements of the subjective/intersubjective infrastructure. The coexistence of natural and phenomenological attitude is imperative in this context. The omission of the natural attitude is equivalent to

8 Anticipation is, therefore, the temporal expression of the radicalisation of intentionality as the opening of ego-cogito to its object, on a fusion of itself with it, on a horizon. It should be thought as a temporal de-distancing in Heideggerian terms, the Entfernung of the subject to itself in position. 
Croatian

International

Relations

Review

$-$

CIRR

-

XXVI (86) 2020,

$42-70$ suppressing the contents of the study. Likewise, the omission of the phenomenological attitude is equivalent to erasing the subjective-intersubjective framework and dynamics. Therefore, the conduct of the study shall alternate between the two attitudes to define both and fit them together. Epoche is to constitute the link between the two.

The positional temporality of the actor(s) involved and the systemic temporality on the standard reference to the intersubjective environment are to be defined when studying a specific phenomenon as to its framework of the constitution. The contents related to the phenomenon thus will be set into the framework posited through this subjective/intersubjective framework. Without prejudice to the causal content of the phenomenon, the link with its subjective/intersubjective infrastructure is to be established. The assessment thus becomes possible for the causal contents as well as for the noetic-noematic modalities of positing through each other.

\section{Constitution of the unipolarity and Ukrainian positioning}

\section{The systemic temporality of the early Post-Bipolar era}

We should begin with a clarification on our employment of the terms pertaining to "polarity" which belong to the structural realist approaches. Polarity terminology and the underlying line of thought have been criticised as to their adequacy and even validity in-depth, through ample argumentation related to their very own context, parameters, and assumptions (see especially the 11 points of Gardner 2019:39-60). Their presence in our work, as shall be seen, is out-of-context. Polarity terminology gains adequacy in our work in its quality to express the coreference to the intersubjective environment in temporal shaping of positioning and positions of the actors. Otherwise, our position had been made clear in the first chapter.

Bipolarity/bipolarisation may be defined through epoche that would suspend the contents that are attributed to it, like the causal parameters of the distribution of power and its various forms and criteria (Waltz 1979: 161-193, De Keersmaeker 2018: 16-21, Wagner 1993), as well as issues of behavioural patterns of sociology/psychology and derivatives, as merely as a 
Croatian

International

Relations

Review

$-$

CIRR

$-$

XXVI (86) 2020,

$42-70$ systemic reference to a central duality as noematic core of the intersubjective environment of the actors.

Systemic reference as the noematic core of intersubjectivity's constitution posits the fundamental directionality of the actors in relation to the intersubjective environment. In that sense, bipolarity's central duality becomes a priori to its contents in its duration, even if its roots may arguably be purely causal. The bipolarity is first established as the basic shape of the intersubjective environment. It then transcends effectively the causal criteria formulated/observed a posteriori through objectivisation. For example, the distribution of power within the system as the choice spectrum of data becomes itself arguable as valid criteria of explaining bipolarity; however, the bipolar reference remains intact. In other words, the system's bipolar/bipolarised noematic core influences even how the causal data are selected and interpreted.

On the other hand, bipolarity as the systemic reference-despite its evolution in its duration - remains valid as long as the central duality remains intact. The disintegration of the USSR is not, in this sense, the end of bipolarity. There is, namely, the sudden alteration of the distribution of power - which is a posteriori and not truly determining due to the nature of the bipolar distribution of power. It would not be wholly incorrect to state that the ultimate balance between the two poles resided on the nuclear equilibrium especially during the late phase of bipolarity, which remained intact ${ }^{9}$ - but because of the intersubjective experience of invalidation of the central duality itself.

The end of the central duality to which the system's actors referred in their positioning marks the end of bipolarity. Nevertheless, what is the subjective/intersubjective meaning of the "end"? On suspension of simple causal interaction, we have a change of modality in subject's relatedness to a phenomenon, which is the transition from "affirmation" to "invalidation", effectively a change of "sign" related to the otherwise intact phenomenon. The bipolar reference's invalidation, in its turn, gives us only an invalidated phenomenon and not imperatively its suppression. The suppression of a fundamental reference as if it did not exist (or more correctly, its total transfer into the

9 It is certainly true that a post-Soviet economic collapse occurred (Tsygankov 2016: 86 - gives a succinct description). However, in no moment, the fundamental balance of power residing on mutually assured destruction has been modified. 


Croatian
International
Relations
Review
-
CIRR
-
XXVI (86) 2020,
$42-70$

Croatian International Relations

sphere of "recollection") is existentially impracticable. That would mean the suppression of retention itself, of the actor's positioning, as well as of the systemic reference. That would, therefore, mean the suppression of the "now" in its constitution for the system and the actor.

Therefore, even after its change must the systemic reference be retained on that altered modality. As for the actors' positional temporality, the alteration imposes a change according to that of a systemic reference. In that sense, the actor retains its position on the alteration of that of the systemic reference, preserving it through different modalities (Bogdanov 2017º).

Concerning the poles themselves, the bipolar era was undoubtedly characterised by the fusion of their positional temporalities with the systemic temporality even beyond the systemic reference within their noetic-noematic processes. Their positional temporalities were not shaped in reference to the system. Instead, the system was a priori constituted through their positions.

Consequently, the retention of the position of the "intact" pole on the alteration of the systemic reference engendered the "unipolar moment" (Krauthammer 1991) even without the experience of the change in power distribution. In other words, in terms of systemic reference, a priori to the actual contents that follow, the invalidation of bipolarity as retained equated the unipolarity (see for various definitions on power-distribution and behavioural patterns with consequent predications/ judgements that may be reduced to that point, Jervis 2009, Huntington 1999, Ikenberry, Mastanduno, Wohlforth 2011, Finnemore 2011, Monteiro 2014: 40-41, Beckley 2018: 100-113). For the intact pole and the actors positioned in proximity to it, there were no position-altering influences due to the change in the systemic reference. The brief history of the unipolarity may phenomenologically be reduced to the fact that the "intact" side continued with its bipolar-position as retained other than discourse appropriate to the new state of affairs.

For the Russian Federation, which was entirely automatically referred to as the successor of the USSR, the retention of the

10 Bogdanov stresses, indirectly, this fundamental retention in his chapter; however within the "objectivised" field of the IR and recommends a compromise/clarification of the normative nature in the new era. 


Croatian
International
Relations
Review
-
CIRR
-
XXVI (86) 2020,
42-70

Croatian International Relations systemic reference was no different in substance, but on a relevant change of modalities. The self-retention of the actor on the invalidation of the systemic reference produced a different sort of position within the unipolar moment that evolved within the systemic temporality. Unipolarity's formative phase, if translated into a positional adaptation based on continuity for the US, became for the Russian Federation its transformation into something else (see Tsygankov 2016: 59$\left.96^{11}\right)$. The fundamental policy papers of the Russian Federation at that time, even during Tsygankov's "liberal Westernist" period manifest that, in the form of promoting the end of a bipolar era (for the West) while retaining a bipolar-like position for Russia in that very "promotion" (Melville, Shakhleina 2005) ${ }^{12}$. This coincides well with other policy contents, especially with the frozen conflicts in the "near-abroad" and limited rallying attempts of the ex-USSR geography in a loose and mostly inefficient arrangement under the CIS (see Kobrinskaya 2007).

For Ukraine and the other new independencies, the formation of their positional temporalities was more complicated. Their retention of the USSR had to be radically different from that of the Russian Federation. They were posited by the dismemberment, instead of being dismembered. The said does not imperatively engender antagonism with what is retained as a modality of their positioning; however, they accommodate more easily with the unipolar moment as systemic reference. Moreover, their positional horizon was inherently broader than that of the Russian Federation since they did not retain a position of the pole - even on invalidation. Still, the retention of the USSR was necessarily there, not as a systemic reference but as positional contents towards Russia. From there emanated the existential conflict potential that led to frozen conflicts and beyond.

11 It is interesting to see that the same subjective/intersubjective reference produced, within the Russian positional temporality, different contents arguably evolving towards adequacy in the experience of the intact retention of the bipolar-self for the US and the "West" as "unipolar acts". Tsygankov depicts the earliest as post-bipolar euphoria and liberal Westernism for Russia.

12 See for the early foreign policy, national security concepts and military doctrine papers from 1993 to 2000 . The main elements related to the system include "the end" of bipolarity, concern over the US possible unipolar attitude, the need for and tendency towards a multicentred/multipolar world order, the primacy of the UN - and the OSCE - and the place of Russia as a great power, in a defacto bipolar position in relation to the main western organisations and actors. 


Croatian
International
Relations
Review
-
CIRR
-
XXVI (86) 2020,
$42-70$

Croatian International Relations $42-70$

\section{Ukraine's becoming content of Russian and Western positions within the systemic temporality}

Constituting itself in a position within the altered intersubjectivity has perhaps been more controversial for Ukraine than all the other new independencies. The Ukrainian "We-subject (see Carr 1991: 122-127)" was constituted on an immanent contradiction. The country was divided between - mainly - Ukrainian and Russian affiliations based on linguistic separations rather than declared ethnicity ${ }^{13}$ and in potentially pro-western and pro-Russian factions susceptible to create pulls in opposite directions in Ukrainian positioning, depending on the state of Russian-Western relations which equated systemic reference.

The derived-subject/actor is constituted primordially as $a$ spatial being with a far better-defined space than ego-cogito, to the point that spatiality equates Leib (see Husserl 1982: 108-112) ${ }^{14}$. Now, what if the Leib or the self-experience of Leib is inherently incoherent, incoherence itself being a core phenomenon of the subject's position? For Ukraine what was spatially coherent was the inner division and not the outer "posture", factions being accumulated in different parts of the country (see O'Loughlin, Toal and Kolosov 2017 for an insightful paper on the concept of Russkiy Mir in the geography). Pro-Russian (or only Russian) parts were in proximity with Russia as the surveys, elections and then the crisis would demonstrate.

For Crimea, Russian affiliation on ethnic15 and especially linguistic ${ }^{16}$ bases was absolute. Crimea became Ukrainian territory admittedly due to a strange rectification of (inner) borders during Khrushchev's era (Gardner 2015: 43-44). It would not be wrong to say that the Peninsula became the prominent content of the inherent incoherence of Ukraine's positioning within the system. It is to be remembered that the Peninsular Parliament declared independence from Ukraine as early as in 1992, although it was not implemented (Bebler 2015). Crimean

13 http://2001.ukrcensus.gov.ua/eng/results/general/nationality/ [accessed 22 April 2020]. http://2001.ukrcensus.gov.ua/eng/results/general/language/ [accessed 22 April 2020].

14 The equivalent of position for the derived-subject is the term Leib for ego-cogito on the real/causal plane as the primary mode of the subject that gives itself in experience appresenting a monad, or in more general terms in our study, subjecthood.

15 http://2001.ukrcensus.gov.ua/eng/results/general/nationality/ [accessed 22 April 2020].

16 http://2001.ukrcensus.gov.ua/eng/results/general/language/Crimea/ [accessed 22 April 2020]. 


Croatian
International
Relations
Review
-
CIRR
-
XXVI (86) 2020,
$42-70$

Croatian

International

Relations

Review

CIRR

XXVI (86) 2020

$42-70$
Constitution was adopted six years later. The autonomy was weak. Crimean Parliament had no competence to adopt laws. The language issue was more or less hanging in the air, and the "rising Ukrainian nationalism" undoubtedly irritated the Crimean population as it did in the southern and eastern regions of the country (Wydra 2014). In addition to Crimea, the census figures for Donetsk ${ }^{17}$ and Lugansk ${ }^{18}$ were of the same nature.

At that stage, it would be correct to stress that the existential uniqueness/erratic positional temporality of Ukraine resulted in its being bound almost entirely to the systemic temporality. Ukraine was not placed in the Russian near abroad similarly to Belarus, nor was able to constitute itself in line with "western bloc" as Poland or the Baltic states. Consequently, the incoherence was the modality of Ukrainian positioning within the system. That has been, therefore, the main existential particularity of Ukraine that defined the others' positioning regarding her. The incoherence might have been sterile if it was not related to altered systemic reference within its temporality. It did not immediately become "fertile" either during the early phase of unipolarity. Although the Western and Russian positions were substantially diversifying as regards their modalities related to the altered systemic reference, dividing lines were not fully formed.

The earlier wave of NATO enlargement ${ }^{19}$ and the EU expansion more or less parallel to the former, the Kosovo crisis of 1999 and the Second Iraqi War that followed in 2003 (Zacklin 2010: 91-154) ${ }^{20}$ constituted observable contents of passage into a new phase of the systemic temporality. Hence, Russian and Western modalities as regards the systemic reference (multipolarism versus and within unipolarity as different modalities of retention of the invalidated-bipolarity) became visibly more diversified.

Even more important than those, due to their relatedness to "near-abroad", colour revolutions and GUAM (Simon 2008: 93)

17 http://2001.ukrcensus.gov.ua/eng/results/general/language/Donetsk/ [accessed 22 April 2020].

18 http://2001.ukrcensus.gov.ua/eng/results/general/language/Luhansk/ [accessed 22 April 2020].

19 The Czech Republic, Hungary and Poland

20 For the main argument of disregarding the UN Security Council (and Russian veto right) within the international law debate. 


Croatian
International
Relations
Review
-
CIRR
-
XXVI (86) 2020,
$42-70$

Croatian International Relations $42-70$ constitute two critical developments that indicate the state of the unipolar moment within the systemic temporality, in addition to NATO enlargement of 2004 (Simon 2008: 102-103). They added contents to the positional and systemic rift between Russia and the West. The revolutions in Ukraine and Georgia were pro-western and consequently, at the current state of the systemic temporality, anti-Russian. Georgian revolution set the anti-Russian position far easier than Ukrainian one though, for the secession had already occurred there.

As for Ukraine, the Orange revolution (Coyle 2018: 42-46), while having changed the faction in power, neither substantially weakened the opposing one nor succeeded to transform its prowestern inclination into a stable and robust position within the system. The presidential elections in 2004, for example, among others, showed the spatial division and general balance spectacularly (Van der Pijl 2018: 38-41)21. Still, following the new wave of NATO enlargement of 2004, at the current stage of its erratic positioning, Ukraine initiated the "intensified dialogue" mechanism with NATO in $2005^{22}$. Ukraine's application for membership followed suit in 2008 and faced a hard-line Russian reaction by Putin at the NATO Bucharest Summit of the same year (Coyle 2018: 47-48).

At that phase of systemic temporality as reflected on the reciprocal positions of Westerners and Russia, Ukraine's becoming content of the evolving state of affairs is the result of its non-becoming a stable actor due to its fundamental incoherence of positioning. On the other hand, in contrast to Georgia or Moldova, this incoherence proved to be sustainable. Ukraine's inner division, as we tried to outline in the previous section, was balanced. Both factions had about the same chance of acquiring power over the entire country, so separatism was not imminent. Moreover, in line with the actor's becoming itself a content of the systemic-level positioning of the related actors, that balance was open to influences that would stem from or touch upon the reciprocal positions of Russia and the Westerners. In contrast to Georgian or Moldovan cases where positional temporality was stabilised by secession, in Ukraine, the

21 See also Paniotto, Volodymyr, “Ukraine: Presidential Elections 2004 and the Orange Revolution."

https://www.kiis.com.ua/materials/articles/president\%20election\%20in\%20 ukraine\%202004.pdf [accessed 22 April 2020].

22 https:/www.nato.int/docu/update/2005/04-april/e0421b.htm [accessed 22 April 2020]. 


Croatian
International
Relations
Review
-
CIRR
-
XXVI (86) 2020,
$42-70$

Croatian

International

Relations

Review

CIRR

XXVI (86) 2020,

$42-70$

absence of such an inner imbalance held the country together and the position incoherent.

For the West, the enlargement of the Alliance, the EU and the promotion of "universal" values continued on the unipolar reference. On the other hand, Russian "fundamental papers" continued to be good indicators of a gradual multipolarist volteface on the same systemic reference ${ }^{23}$. The criticism of western normativism and universalism added to it increasingly (Chebankova 2017). The reflects on Ukraine as the content of reciprocal systemic positioning constituted the intersubjective inevitability of the crisis that gained content in 2014.

\section{Crimea and the new phase of systemic temporality}

\section{Crisis and annexation}

Ukrainian Crisis of 2014 occurred as the content of a newer phase of the unipolar systemic temporality. Western "unipolarism" was facing, at least since the Georgian Crisis of 2008, determined opposition from Russia, which included direct acts on the same systemic reference. Russian positional horizon was narrowed within the unipolar temporality as demonstrated by her direct intervention not only into a frozen conflict zone but also into the territory of a prowestern government (Asmus 2010). On that instance, Georgia did not receive credible support from the West. Moreover, her NATO membership aspirations were de facto stalled (Kipiani 2015). Finally, through the "reset period", Georgian case was circumvented in Western-Russian relations. In other words, following an initial reaction, neither the US nor the EU truly countered Russian volte-face (Mikhelidze 2015).

Increased systemic pull on Ukraine made its position more fragile. Ukraine's NATO and EU membership perspective was

23 The "papers" highlighted the "policy of containment against Russia", the threat assessment of NATO expansion, the "plans of admitting Ukraine and Georgia" into the Alliance and attributing global functions to NATO in violation of international law. A European security treaty "from Vancouver to Vladivostok" was proposed as an alternative to "bloc-based approaches".

https://russiaeu.ru/userfiles/file/foreign_policy_concept_english.pdf [accessed 22 April 2020]; https://carnegieendowment.org/files/2010russia_military_doctrine.pdf [accessed 22 April 2020];

https://www.rusemb.org.uk/in1/ [accessed 22 April 2020]. 


Croatian
International
Relations
Review
-
CIRR
-
XXVI (86) 2020,
$42-70$

Croatian International Relations Review $42-70$

naturally an aim of the pro-western faction. However, there has been a general wavering of the public opinion on that matter in troubled times, such as the Kosovo conflict (Kalb 2015: 127). NATO and EU membership meant an irreversible engagement in providing the country with a western-anchored position that would appresent a rupture with Russia (Donaldson 2017). In parallel, "the protection of Russian communities abroad" gained strength in the Russian political discourse, extending to a broad interpretation of self-determination and of the western expansionism (linking the Kosovo example of selfdetermination and humanitarian intervention with Abkhazia and South Ossetia, as the precursor of Crimea in arguments, see Tuathail 2008, Nielsen 2009), further fuelling the internal division of Ukraine (Teper 2015) ${ }^{24}$.

On the political scene, the division did not allow a clear preponderance for one part over the other. Yanukovich won the 2010 presidential election by a narrow margin over Timoshenko. The election results had the same geographical characteristics of 2004. Yanukovich had the advantage of the rift between the "Orange Revolution" leaders ${ }^{25}$ as a secondary balance-tipping factor. In the Peninsula, separatism - and joining Russia was supported right after the Georgian War of 2008. Still, this support declined to a minority after Yanukovich's access to power (Katchanovski 2015). Knott's work related to identities in Crimea in the pre-annexation period offers further insight as to the fluctuations of the identity-related opinion by introducing more categories (Knott 2018).

Following Yanukovich's access to power in 2010, the new government undid the pro-western acts of the former one, in conformity with the actor's positional incoherence. Ukrainian Parliament adopted a law guaranteeing the non-alignment of the country ${ }^{26}$. The same year President Yanukovich signed the Kharkiv Pact to prolong the lease of Sevastopol navy base - the main base of the Russian Black Sea Fleet - to Russia until 2042 (Gardner 2015: 63, Delanoe 2014, Van der Pij1 2018: 72).

24 See also: "What Is Happening in Ukraine and What Kind of Future Awaits It?" Russian Social Science Review, 2017, 58:2-3, Pp. 170-211

25 Contributed by N. Kharchenko (Executive Director) and Vladimir Paniotto (Director General) Kyiv International Institute of Sociology “The Ukraine Presidential Election: Comparing the 2010 and 2004 Exit Polls" https://www.kiis.com.ua/materials/articles/ The\%20Ukraine\%20Presidential\%20Election.pdf [accessed 22 April 2020].

26 https://www.bbc.com/news/10229626 [accessed 22 April 2020]. 


Croatian
International
Relations
Review
-
CIRR
-
XXVI (86) 2020,
$42-70$

Croatian

International

Relations

Review
Another point of contradiction within this framework was the EU perspective for Ukraine and the new Russian-led Eurasian Union as an alternative (see Libman, Obydenkova 2018 ${ }^{27}$ ). The same regional contrast manifested itself for the support to EU and EAEU (Wydra 2014).

Yanukovich government's decisive moment seems to have been the non-conclusion of the EU Association Agreement in late $2013^{28}$ (Mantovani, Rickenbacher 2014). Pro-western (or antiRussian) faction initiated Euromaidan. Yanukovich, after a losing struggle, left the country. A new administration accessed to power (Van der Pij1 2018: 69-86), appresenting-in-anticipation of the Ukrainian positioning EU over Eurasian Union, West and even indirectly NATO over Russia and a shrinking of the Russian positional horizon related to Ukraine and through Ukraine, in the systemic temporality.

Russian and pro-Russian reaction is well known. Crimea seceded and requested to join the Russian Federation. Russia intervened, and Ukrainian presence disappeared from Crimea and Sevastopol. Russia annexed Crimea in March 2014, following a referendum in the Peninsula. The pro-Russian faction also seceded in Donetsk and Lugansk and with Russian support succeeded in maintaining their space (Kalb 2015: 158-179).

\section{Positional and systemic implications of the crisis}

Civil conflict and the annexation effectively put an end to Ukrainian incoherence which had constituted the noematic core of its position within the systemic temporality. Kyiv became an actor rather than a mere content, with the coherence gained from the secession. With Crimea and the pro-Russian provinces gone, Kyiv firmly and perhaps irreversibly anchored itself to the West, at least concerning its retention-protention and positional horizon. If Ukraine is unable to alter the current state of the Peninsula, its position equally may not be altered without force majeure. As contents appropriate to this clarified positioning, Ukraine signed the EU Association Agreement in 2014, cancelled its non-alignment law and reinstated NATO

27 On the EAEU as the content of Russian multipolarist positioning in near-abroad, with varying forms regarding the actor in question.

28 The text of the Agreement as signed in 2014 by the new government: http://trade. ec.europa.eu/doclib/docs/2016/november/tradoc_155103.pdf [accessed 22 April 2020]. 


\begin{abstract}
Croatian
International

Relations

Review

-

CIRR

$-$

XXVI (86) 2020,

$42-70$

membership as a strategic foreign policy objective in $2017^{29}$.

On the other hand, as a content related to the constitution of the system, it also became synonymous with the demarcation between the two different modalities of referencing the intersubjectivity, mainly due to the annexation, therefore Crimea, rather than the other secessionist entities which posited new frozen conflicts more or less similar to the precedents.
\end{abstract}

Crimea's importance resides at the meaning of annexation, rather than the strategic value of the Peninsula. By annexing and effectively militarizing the peninsula, Russia certainly gained a relatively advantageous position in the Black Sea at least at first sight. However, it is also correct that the Russian superiority is only meaningful in its relationship with its potential opponents, namely NATO countries. It depends rather on the presence of armaments, navy/anti-navy and air assets in the theatre and especially on the rigorous implementation of the Montreux regime which has been implemented most rigidly since its conclusion, denying the non-riparian allied navies meaningful access (in terms of tonnage and timespan) to the Black Sea ${ }^{30}$.

The annexation marks a new phase in the systemic temporality which largely surpasses its concrete consequences. Russia at one side and the "West" on the other side are solidly engaged in their positional differences with Crimean content. Not the status of a region but the spatiality of a subject itself is being contested continuously within the systems' intersubjectivity. Before the annexation, there were differences within the spatiality of an actor, defining its positioning on the engendered incoherence. Contested at that point was not even the spatiality-as-Leib of Ukraine but its position within the unipolar system. The annexation transferred the "problem" to Russia's spatiality and heightened it to systemic level from the positional temporality of Ukraine.

The annexation does not only crystallise in-system positioning of the two sides in relation with one another; it does not stay

29 https://www.defensenews.com/global/europe/2017/06/09/ukraine-parliament-restoresnato-membership-as-strategic-target/ [accessed 22 April 2020].

30 The Montreux Convention: Receuil des Traités, Société des Nations, Vol. CLXXIII 19361937, No: 4015 


Croatian
International
Relations
Review
-
CIRR
-
XXVI (86) 2020,
$42-70$

Croatian

International

Relations

Review

CIRR

XXVI (86) 2020,

$42-70$ local either. It becomes part of the positional temporalities of the two sides as it refers to the intersubjective shape of unipolarity on rigidified and contradictory modalities. In Syria or even in Venezuela, the two sides face each other, or RussianChinese relations gain momentum. For the latter, not only the bilateral cooperation but also the institutional cooperation, be it within the UN Security Council or at regional/continental level ones (SCO, even Belt and Road) become emphasised (see Feng and He 2017 for Chinese institutional conduct of its multipolarism).

As for Russian positional temporality, in contrast with Donetsk and Lugansk where the conflict has been "internationalised" with the OSCE special monitoring mission, ${ }^{31}$ the annexation of the Peninsula constituted an irreversible development. It could hypothetically be like Abkhazia and South Ossetia, which are just short of being formally annexed (see Ambrosio and Lange 2016). On the other hand, within the systemic temporality, frozen conflicts did not resolve the question of western "unipolar" acts. As mentioned at the beginning, secessionist entities had to be supported continuously by Russia in order make them viable (see Gerrits, Bader 2016 for the afterwards of 2008 crisis in Abkhazia and South Ossetia, see German 2016 for South Ossetian developments). Moreover, the actors who had to face secessionist movements invariably anchored their positions to the West. Russian positional horizon in its ancient geography continuously narrowed down with each conflict situation. Lastly, those frozen conflicts proved to be circumventable. Advantageous at face-value for Russia, they meant at the same time that no radical change in western positions would be necessary while maintaining the liability of secessionist entities for Russia. Phenomenologically, it was the positional equivalent of slow drowning for the Russian subject.

Russian conduct during the Ukrainian crisis may thus be defined as a positional and progressively systemic remedy to this phenomenon. The Russian affiliation of the Peninsula and the arguable Kosovo-precedent provided convenient contents. As the success of Euromaidan already meant the loss of Ukraine, the annexation of the Peninsula became a possibly viable option. It imposed a dividing line that went beyond the almost inconsequential creation of frozen conflicts as regards 


Croatian
International
Relations
Review
-
CIRR
-
XXVI (86) 2020,
$42-70$

Croatian International Relations $42-70$
Western positioning. Crimea thus means, a priori to its contents, a systemic level position-taking engaging Russian position frontally to balance and narrow the western unipolarist horizon.

Consequent momentum gain of the Russian pivot to the East - particularly the cooperation with China - constitutes a content appropriate to the new phase rather than a cause-effect relation with Western sanctions or a "choice" inherent to the objectivised reality (in contrast to Korolev's reasoning on his correct analysis of contents - Korolev 2016 as well as in contrast to Lukin's description as a "natural" development despite his stress on Russian and Chinese "polycentrist" convergence Lukin 2018)

The annexation was not recognised. Nevertheless, it showed anti-unipolarist (or multipolarist, stressing its difference from multipolar) positions within the system more clearly (Lewis 2018) ${ }^{32}$ : For example, the contrast in BRICS' attitude between Libyan and Ukrainian crises at the UN shows the prevalence of that systemic-level directionality over contents (see Brosig 2019 81-86; 149-151). In fact, Crimea provided content to the divergences between several prominent actors as regards the modalities of systemic referencing, marking its new phase.

As for the West, Crimea constitutes a unifying and diversifying content at the same time, depending on the actors' modalities of referring to the new phase of the systemic temporality. Non-recognition of the annexation, support for the Ukrainian government, sanctions against Russia (and Russian countersanctions), related NATO/EU and individual western countries' discourse are certainly among the unifying elements. On the other hand, the inner incoherence also appears through the same elements. Western sanctions against Russia since 2014 have proved to be mostly inefficient and have been maintained so (Shchetinskaia 2016, Frye 2018). The support to the Ukrainian government has been "token" with arguably no influence over the balance of power between the two actors. Ukraine has not received a MAP from NATO, and no expansion is on the horizon. No EU expansion towards Ukraine (or Georgia) is seriously foreseen.

32 Lewis diagnoses the multipolarist volte-face correctly as an attempt for a "new geopolitical space from Budapest to Beijing in which the liberal norms of the international order are being challenged", yet without touching the positional and systemic intersubjective "determinism" that engenders it. So, the diagnosis' arguments, while valid, lack the "explanatory tool" that would go beyond the sphere of contents. 


\begin{abstract}
Croatian
International

Relations

Review

$-$

CIRR

$-$

XXVI (86) 2020,

$42-70$

The new phase of post-bipolar intersubjectivity thus stresses the inconsistencies in the western positions paradoxically by imposing coherence upon them. In other words, if the Crimean act narrowed the Russian positional horizon and rigidified its modality related to the systemic reference in a different manner than had been until that moment, it did the same to the western positions. However, such a narrowing of positional horizons among the western actors did not entirely fit in a consistent directionality.
\end{abstract}

\section{Conclusion}

The multipolarism as Russian modality to refer to the unipolar system had not rigidified to the point of positing an in-system alternative for the earlier phases of the post-bipolar intersubjectivity. Similarly, the unipolarity was referred to in "western" positioning only as retention of the self in bipolarera with no symmetrical resistance. The new systemic phase that retains less the bipolar positioning on "invalidation" and passes the retention-protention into a more authentic phase on validation (in differing modalities) of unipolarity is likely to constitute the phenomenological basis of the new state of affairs. Ukrainian crisis and annexation marked the passage as content.

Multipolarist volte-face of the new phase underlined particularly by the Crimean act narrowed the westerners' positional horizons by narrowing its own. It accentuated the divergences, at subjective/intersubjective level of positioning, among the western actors. On the other hand, following the apparently risky Crimean act, the multipolarist stance within the unipolar system has become more coherent. Many prominent non-western actors showed limited solidarity with Russia, which may be described as constructive abstention on the delicate matter of Crimea. A more substantial positional - getting - systemic content modification has undoubtedly been the gain of momentum in Russian-Chinese strategic cooperation (for example, Lanteigne argues that the "Crimean shadow" may impede the cooperation especially in security matters and Kuhrt and Buranelli stress Chinese preponderance potential in this relationship. Recognising the validity of those as contents, we think that the synchronised systemic level directionality compensates them as Lo underlines, yet 


Croatian
International
Relations
Review
-
CIRR
-
XXVI (86) 2020,
$42-70$

preferably in terms of contents and still not as the existential terms: Lo 2008: 180-183, Lanteigne 2018, Kuhrt and Buranelli 2017). Moreover, other international "hotspots", not causally related to Russian near-abroad as in previous phases, have begun to be more or less balanced against western influences, including direct Russian military engagement in the Syrian case.

History does not lack examples of systemic-level changes made visible (and not caused) by relatively small-scale incidents as contents. Saguntum, Roman ally yet situated south of Ebro was one of them. Its fall marked a new phase in that intersubjectivity of Roman-Punic dialectic with well-known consequences. In a purely objectivised analysis, Saguntum and the "new phase" would appear avoidable in innumerable ways. On a phenomenological approach though, the inevitability of the new phase itself (regardless of a particular content) might be assessed through the study of the retentional-protentional positioning of the actors following the First Punic War, which is not different from the end of the bipolar era.

In a way, Crimea is a new Saguntum. On the other hand, the noetic-noematic processes of actors as regards the positional, as well as the systemic temporality, exist independently from that particular content. The content itself gains meaning within the framework of reality they constitute.

By extending the analogy towards the contents, it would not be wrong to state that Carthage constitutes itself in a coherent position. Roman unipolarity, however, has been struggling to preserve First Punic War-level coherence with its Italian allies within the new phase of systemic temporality marked by Saguntum's fall.

\section{Bibliography}

Ambrosio, T.; Lange W.A., 2016. The Architecture of Annexation? Russia's Bilateral Agreements with South Ossetia and Abkhazia, Nationalities Papers. 44 (5): 673-693.

Anderson, M. S., "The Great Powers and the Russian Annexation of the Crimea, 1783-4". The Slavonic and East European Review. Vol. 37, No. 88 (Dec., 1958).

Asmus, R.D., 2010. A Little War That Shook The World: Georgia, 


Croatian
International
Relations
Review
-
CIRR
-
XXVI (86) 2020,
$42-70$

Russia and the Future of the West. New York: Palgrave McMillan.

Bebler, A., 2015. The Russian-Ukrainian Conflict Over Crimea. Teorija in Praksa. let. 52, 1-2: 196-219.

Beckley, M., 2018. Unrivaled: Why America Will Remain the World's Sole Superpower. Ithaca and London: Cornell University Press.

Bogdanov, A. 2017. Preserving Peace Among the Great Powers: Russia's Foreign Policy and Normative Challenges to the International Order. In: Kanet R.E., The Russian Challenge to the European Security Environment. Cham: Palgrave Macmillan, pp. 37-58.

Brosig, M., 2019. The Role of BRICS in Large-Scale Armed Conflict: Building a Multi-Polar World Order. Cham: Palgrave Macmillan.

Carr, D., 1991. Time, Narrative and History. Bloomington: Indiana University Press.

Carr, D., 1987. Interpreting Husserl: Critical and Comparative Studies. Dordrecht: Martinus Nijhoff.

Chebankova, E., 2017. Russia's Idea of the Multipolar World Order: Origins and Main Dimensions. Post-Soviet Affairs. 33(3): 217-234.

Coyle, J.J., 2018. Russia's Border Wars and Frozen Conflicts. Cham: Palgrave Macmillan.

De Keersmaeker, G., 2017. Polarity, Balance of Power and International Relations Theory: Post-Cold War and the 19th Century Compared. Cham: Palgrave Macmillan.

Delanoe, I., 2014. After the Crimean Crisis: Towards a Greater Russian Maritime Power in the Black Sea, Southeast European and Black Sea Studies. 14:3: 367-382.

Donaldson, R.H., 2017. The Role of NATO Enlargement in the Ukraine Crisis, The Soviet and Post-Soviet Review. 44: 32-52.

EU-Ukraine Association Agreement: http://trade.ec.europa.eu/ doclib/docs/2016/november/tradoc_155103.pdf [accessed 22 April 2020].

Feng, H., and He K., 2017. China's Institutional Challenges to the International Order. Strategic Studies Quarterly. 11(4): 23-49.

Finnemore, M., 2011. Legitimacy, Hypocrisy, and the Social Structure of Unipolarity: Why Being a Unipole Isn't All It's Cracked Up to Be. In: Ikenberry J., Mastanduno, M., Wohlforth W.C. eds. International Relations Theory and the Consequences of Unipolarity. New York: Cambridge University Press, pp. 67-98. 


Croatian
International
Relations
Review
-
CIRR
-
XXVI (86) 2020,
$42-70$

Croatian International Relations Review
Foellesdal, D., 2005(1969). Husserl's Notion of Noema. In: Bernet R., Welt D.; Zavota G., eds., Edmund Husserl: Critical Assessment of Leading Philosophers Volume IV: The Web of Meaning: Language, Noema and Subjectivity and Intersubjectivity. London: Routledge, pp. 161-168.

Frye, T., 2018. Economic Sanctions and Public Opinion: Survey Experiments From Russia, Comparative Political Studies. 52(7): 967-994.

Gander, H.H., 2017. Self-Understanding and Lifeworld: Basic Treats of a Phenomenological Hermeneutics. Trns. Ryan DrakeJoshua Rayman. Bloomington: Indiana University Press.

Gardner, H., 2015. Crimea, Global Rivalry and the Vengeance of History. New York: Palgrave McMillan.

Gardner, H., 2019. IR Theory, Historical Analogy, and Major Power War. Cham: Palgrave Macmillan.

German, T., 2016. Russia and South Ossetia: Conferring Statehood or Creeping Annexation?. Southeast European and Black Sea Studies. 16(1): 155-167.

Gerrits, A. W. M.; Bader M, 2016. Russian Patronage over Abkhazia and South Ossetia: Implications for Conflict Resolution, East European Politics. 32(3): 297-313.

Heidegger, M., 1996. Being and Time. Trns. Joan Stambaugh. Albany: State University of New York Press.

Huntington, S.P., 1999. The Lonely Superpower. Foreign Affairs, (March-April), pp. 35-49.

Husserl, E., 1982. Cartesian Meditations. Trans. Dorion Cairns. The Hague: Martinus Nijhoff Publ. (Seventh Impr.).

Husserl, E., 1983. Ideas Pertaining to a Pure Phenomenologv and to a Phenomenological Philosophy (Ideen I). Trans. Kersten., F. The Hague: Martinus Nijhoff Publishers; pp. 221-235.

Husserl, E., 1970. The Crisis of European Sciences and Transcendental Phenomenology. Trans. David Carr. Evanston: Northwestern University Press.

Husserl, E., 1964. Phenomenology of Internal Time- Consciousness. Trns. J.Churchill, Bloomington: Indiana University Press. Ikenberry, J., Mastanduno, M., Wohlforth, W.C., 2011. Introduction: Unipolarity, State Behavior and Systemic Consequences. In: Ikenberry J., Mastanduno M., Wohlforth W.C. eds. International Relations Theory and the Consequences of Unipolarity. New York: Cambridge University Press, Pp. $1-32$.

Jackson, N.J., 2003. Russian Foreign Policy and the CIS: Theories, Debates and Actions. London: Routledge. Jervis, R., 2009. Unipolarity: A Structural Perspective. World 


Croatian
International
Relations
Review
-
CIRR
-
XXVI (86) 2020,
$42-70$

Politics 61(1):188-213.

Kalb, M., 2015. Imperial Gamble: Putin, Ukraine and the New Cold War. Washington D.C.: Brookings Institution Press.

Katchanovski, I., 2015. Crimea: People and Territory Before and After Annexation, Pikulicka-Wilczewska A. And Sakwa R. eds. Ukraine and Russia: People, Politics, Propaganda and Perspectives. E-International Relations, pp. 80-89.

Kennedy, R., 2016. The Limits of Soft Balancing: The Frozen Conflict in Transnistria and the Challenge to EU and NATO Strategy. Small Wars \& Insurgencies. 27(3): 512-537. Kipiani, M., 2015. Georgia's Road to NATO: Everything But Membership?. Warsaw East European Review vol. V. Knott, E., 2018. Identity in Crimea Before Annexation: A Bottom-up Perspective. Kolst $\varnothing$ P.and Blakkisrud H. Russia Before and After Crimea: Nationalism and Identity 2010-2017. Edinburgh: Edinburgh University Press, pp. 282-305. Kobrinskaya, I., 2007. The Post-Soviet Space: From the USSR to the Commonwealth of Independent States and Beyond. In: Malfliet K., Verpoest L., Vinokurov E. The CIS, the EU and Russia The Challenges of Integration. Basingstoke: Palgrave Macmillan, pp. 13-21.

Korolev, A., 2016. Russia's Reorientation to Asia: Causes and Strategic Implications. Pacific Affairs 89 (1): 53-73.

Krauthammer, C., 1991. The Unipolar Moment, Foreign Affairs, 70(1), pp. 23-33.

Kuhrt, N., Buranelli, F.C., 2017. Russia in Asia: Succumbing to China's Embrace?. Asian Surver. 58 (1): 55-64.

Lanteigne, M., 2018. Russia, China and the Shanghai Cooperation Organization: Diverging Security Interests and the Crimea Effect. In: Blakkisrud, H., Wilson Rowe, E., Russia's Turn to the East Domestic Policymaking and Regional Cooperation. Cham: Palgrave Macmillan, pp. 119-138.

Lemay-Hebert, N., 2018. The Frozen Conflict that Turned Hot: Conflicting State-Building Attempts in South Ossetia. Central Asia and the Caucasus. 5(53): 151-159.

Lewis, D.G., 2018. Geopolitical Imaginaries in Russian Foreign Policy: The Evolution of Greater Eurasia, Europe-Asia Studies. 70 (10): 1612-1637.

Libman, A., Obydenkova, A.V., 2018. Regional International Organizations as a Strategy of Autocracy: The Eurasian Economic Union and Russian Foreign Policy. International Affairs 94: 5: 1037-1058.

Lo, B., 2008. Axis of Convenience: Moscow, Beijing, and the New Geopolitics. Baltimore: Brookings Institution Press. 


Croatian
International
Relations
Review
-
CIRR
-
XXVI (86) 2020,
$42-70$

Croatian International Relations Review $42-70$
Lukin, A., 2018. China and Russia: The New Rapprochement. Cambridge: Polity Press.

Mantovani, M., Rickenbacher, D., 2014. Crimea Going East - A Clash of Great Power Strategies. Revue du droit militaire et du droit de la guerre 53/I: 45-67.

Marion, J. L., 1998. Reduction and Givenness: Investigations on Husserl, Heidegger, and Phenomenology. Trns. Thomas A. Carlson. Evanston: Northwestern University Press.

Ed. Melville, A., Shakleina T., 2005. Russian Foreign Policy in Transition: Concepts and Realities, Budapest: Central European University Press.

Mikhelidze, N., (Winter) 2014-2015. NATO-Georgia Cooperation: A Rhetorical Engagement?. Caucasus International 4 (3-4): 44-54.

Monteiro, N.P., 2014. Theory of Unipolar Politics. New York: Cambridge University Press.

Nielsen, C. A., 2009. The Kosovo Precedent and the Rhetorical Deployment of Former Yugoslav Analogies in the Cases of Abkhazia and South Ossetia. Southeast European and Black Sea Studies 9 (1-2): 171-189.

Olbromski, C., 2007. The Category of the (Non-) Temporal "Now" in Philosophy of the "Late" Husserl. In: Phenomenology of Life from the Animal Soul to the Human Mind, Analecta Husserliana. vol.94: 451-458.

O'Loughlin, J., Toal G. and Kolosov, V., 2017. Who Identifies with the Russian World? Geopolitical Attitudes in Southeastern Ukraine, Crimea, Abkhazia, South Ossetia, and Transnistria. Eurasian Geography and Economics.

OSCE Special Monitoring Mission to Ukraine: https://www. osce.org/special-monitoring-mission-to-ukraine [accessed 22 April 2020].

Paniotto, Volodymyr. “Ukraine: Presidential Elections 2004 and the Orange Revolution" https://www.kiis.com.ua/ materials/articles/president\%20election\%20in\%20 ukraine\%202004.pdf [accessed 22 April 2020].

Ricoeur, P., 2005. Husserl's Fifth Cartesian Meditation. In: Bernet, R., Welt, D. and Zavota, G., eds., Edmund Husserl: Critical Assessment of Leading Philosophers Volume IV: The Web of Meaning: Language, Noema and Subjectivity and Intersubjectivity. London: Routledge, pp. 318-344.

Schnell, A., 2010. Intersubjectivity in Husserl's Work. META: Res. in Herm., Phen., and Pract. Philosophy - II (1): 9-32.

Shchetinskaia, I., 2016. Economic Sanctions against Russia after Crimea: Limitations of Impact, North Carolina State 


Croatian
International
Relations
Review
-
CIRR
-
XXVI (86) 2020,
$42-70$

Croatian International Relations

Review

CIRR

XXVI (86) 2020, $42-70$
University Journal of International Studies. Vol. 6, Spring \& Fall.

Simon, J., 2008. NATO Enlargement and Russia. In Braun, A., NATO-Russia Relations in the Twenty-First Century. Abingdon: Routledge - Contemporary Russia and Eastern Europe Series.

Souleimanov, E., 2013. Understanding Ethnopolitical Conflict: Karabakh, South Ossetia, and Abkhazia Wars Reconsidered. London: Palgrave Macmillan.

Teper, Y., 2015. Official Russian Identity Discourse in Light of the Annexation of Crimea: National or Imperial?. PostSoviet Affairs. August: 1-19.

The Montreux Convention: Receuil des Traités, Société des Nations, Vol. CLXXIII 1936-1937, No: 4015.

Tsygankov, A. P., 2016. Russia's Foreign Policy Change and Continuity in National Identity. Fourth Edition. Lanham: Rowman \& Littlefield.

Tuathail, G. Ó., 2008. Russia's Kosovo: A Critical Geopolitics of the August 2008 War over South Ossetia. Eurasian Geography and Economics. 49:6: 670-705.

Ukrainian Census 2001: http://2001.ukrcensus.gov.ua [accessed 22 April 2020].

Van der Pijl, K., 2018. Flight MH17, Ukraine and the new Cold War: Prism of Disaster. Manchester: Manchester University Press. Vaserman, A., Ginat, R., 1994. National, Territorial or Religious Conflict? The Case of Nagorno-Karabakh. Studies in Conflict and Terrorism. Vol.17: 345-362.

Waltz, K., 1979. Theory of International Politics. Reading: AddisonWesley Publishing.

Wagner, R. H., 1993. What was Bipolarity?. International Organization. 47(1): 77-106.

"What Is Happening in Ukraine and what Kind of Future Awaits It?" 2017. Russian Social Science Review. 58: 2-3.

Wydra, D., 2014. What Went Wrong with Crimean Autonomy? Security and Human Rights 25 (3): 312-327.

Zacklin, R., 2010. The United Nations Secretariat and the Use of Force in a Unipolar World: Power v. Principle. New York: Cambridge University Press. 